\title{
NOTE
}

\section{Ten-year observation of sulfur isotopic composition of sulfate in aerosols collected at Tsuruoka, a coastal area on the Sea of Japan in northern Japan}

\author{
NAOFUMI AKATA, ${ }^{1 *}$ FUMITAKA YANAGISAWA, ${ }^{1}$ TAKASHI KOTANI ${ }^{2}$ and AKIRA UEDA ${ }^{3}$ \\ ${ }^{1}$ Graduate School of Science and Engineering, Yamagata University, Yamagata 990-8560, Japan \\ ${ }^{2}$ Tsuruoka National College of Technology, Tsuruoka, Yamagata 997-8511, Japan \\ ${ }^{3}$ Graduate School of Engineering, Kyoto University, Kyoto 615-8540, Japan
}

(Received June 25, 2009; Accepted June 4, 2010)

\begin{abstract}
Atmospheric aerosol samples were collected from 1993 to 2003 at Tsuruoka, Japan, a coastal area on the Sea of Japan. Concentration of water-soluble chemical components and sulfur isotopic ratios of sulfate in aerosol samples were measured to evaluate the temporal variation and identify the source. The ${ }_{\mathrm{sam}} \mathrm{SO}_{4}{ }^{2-}$ and ${ }_{\mathrm{nss}} \mathrm{SO}_{4}{ }^{2-}$ concentrations range from 7.6 to 354.4 and 3.7 to $335.6 \mathrm{neq} \mathrm{m}^{-3}$, respectively, and there was no clear seasonal variation. Sulfur isotope ratios of total sulfate $\left({ }_{\mathrm{sam}} \delta^{34} \mathrm{~S}\right)$ and non-sea salt sulfate $\left({ }_{\mathrm{nss}} \delta^{34} \mathrm{~S}\right)$ in aerosols are +1.0 to +15.1 with a mean value of $+5.7 \%$ and -4.4 to +14.5 with a mean value of $+4.1 \%$, respectively. The values of ${ }_{\text {sam }} \delta^{34} \mathrm{~S}$ and ${ }_{\mathrm{nss}} \delta^{34} \mathrm{~S}$ are relatively low in summer and high in the other three seasons. The ${ }_{n s s} \delta^{34} \mathrm{~S}$ values of aerosols in fall to spring agree with the average sulfur isotope ratios of coal used in northern China, considering the isotope fractionation. These results indicate the possibility of long-range transport of sulfate from the Asian continent to Japan. The variations of atmospheric ${ }_{\mathrm{sam}} \mathrm{SO}_{4}{ }^{2-}$ and ${ }_{\mathrm{nss}} \mathrm{SO}_{4}{ }^{2-}$ concentrations decreased gradually and reach a minimum in 1999. The decline of $\mathrm{SO}_{2}$ emission in China due to reduction in industrial coal use, a slowdown of the Chinese economy, and the closure of small and inefficient plants would be among the causes of this decreasing observed trend. On the other hands, the variation ranges of ${ }_{\text {sam }} \delta^{34} \mathrm{~S}$ and ${ }_{\mathrm{nss}} \delta^{34} \mathrm{~S}$ values abruptly changed after 2000. The introduction of fuel-gas desulfurization technologies to industrial plants of coke production and thermal power stations would be one of the most important causes of this change.
\end{abstract}

Keywords: long-term observation, aerosol, sulfate, $\delta^{34} \mathrm{~S}$

\section{INTRODUCTION}

Atmospheric pollution is one of the most serious environmental problems worldwide. In particular, sulfur dioxide $\left(\mathrm{SO}_{2}\right)$ originating from combustion of fossil fuels such as coal and petroleum is transformed to sulfate aerosols through oxidation reaction in the atmosphere, and the aerosols are scavenged from the atmosphere by rainout, washout, and dry deposition, before finally reaching the ground surface. Therefore, in addition to air pollution, they also cause acid rains.

Long-range transport of anthropogenic pollutants has caused serious environmental problems (Koçak et al., 2004). In the Far East Asian region, including the Japanese archipelago, strong northwesterly winter monsoons from the Asian continent blow to Japan during winter and

*Corresponding author (e-mail: nao@ies.or.jp)

* Present address: Institute for Environmental Sciences, Aomori 0393212, Japan.

Copyright $@ 2010$ by The Geochemical Society of Japan. spring. These monsoons carry air masses including suspended materials from near the surface of the Asian continent (Arndt and Carmichael, 1995). In the Asian countries, the amount of $\mathrm{SO}_{2}$ released into the atmosphere by fossil fuel combustion has generally increased due to rapid economic growth (Guttikunda et al., 2003). It is expected that atmospheric aerosols along the Sea of Japan area contain $\mathrm{SO}_{2}$ emissions from the Asian continent brought by the winter monsoons. Therefore, it is important to understand the concentration level and contribution of longrange transported components in this area.

Sources of atmospheric sulfur compounds are: (1) sea spray $\mathrm{SO}_{4}{ }^{2-} ;$ (2) anthropogenic sulfur such as $\mathrm{SO}_{\mathrm{x}}$; (3) biogenic sulfur such as $\mathrm{H}_{2} \mathrm{~S}$ and DMS (dimethylsulfide); and (4) volcanic sulfur such as $\mathrm{H}_{2} \mathrm{~S}$ and $\mathrm{SO}_{2}$. To clarify the environmental sources of sulfur compounds, Nakai and Jensen (1967) attempted to apply the sulfur isotope ratio $\left(\delta^{34} S\right)$ as a natural tracer. Since then, several groups have reported on the sulfur dynamics in the natural environment by using $\delta^{34} \mathrm{~S}$ values (Fuller et al., 1986; Mukai et al., 2001; Zhao et al., 2003). It has been discussed that $\delta^{34} \mathrm{~S}$ values of non-sea salt sulfate in wet deposition along 


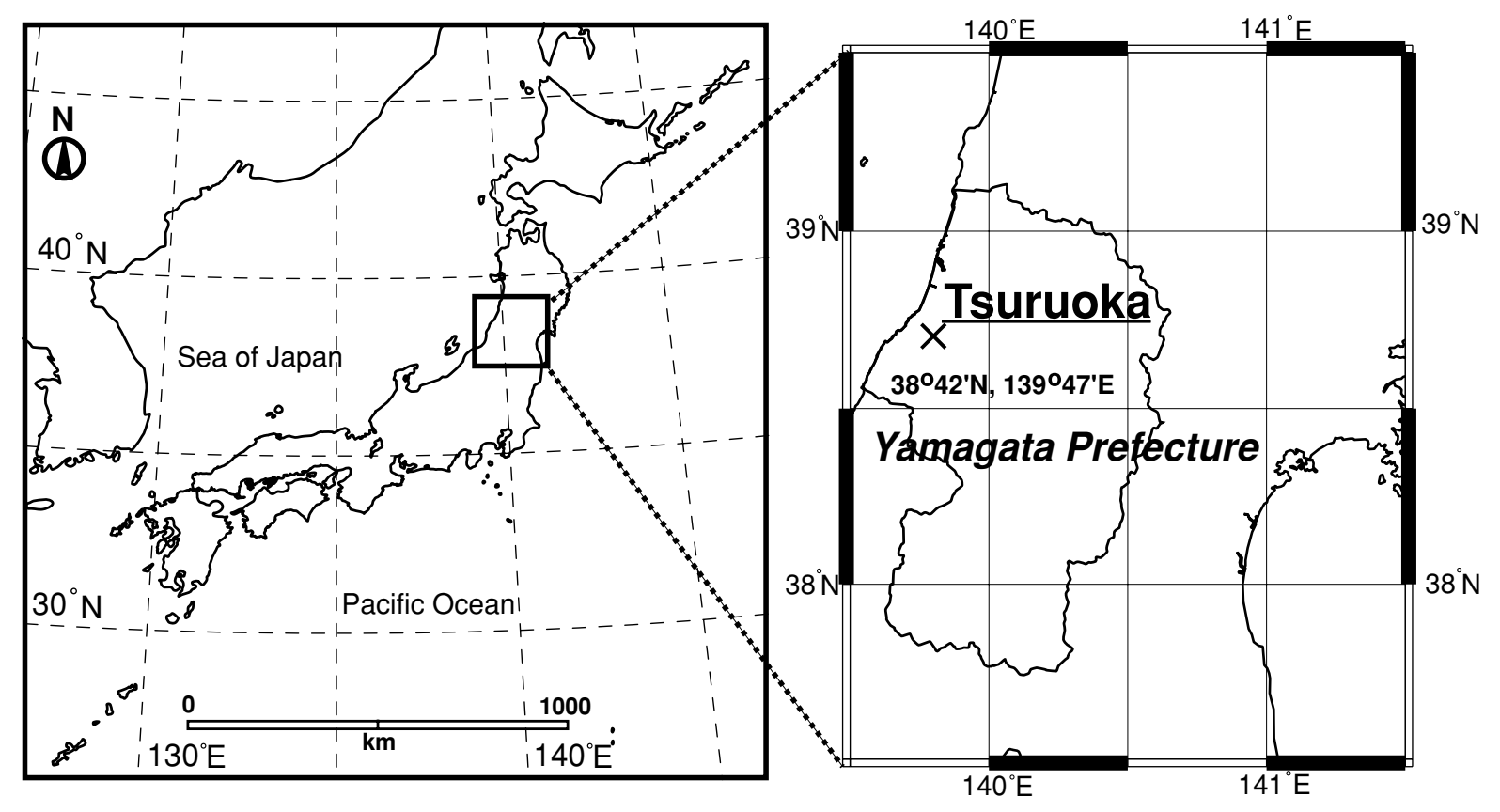

Fig. 1. Location of sampling point.

the Sea of Japan coast of Japan show a clear seasonal variation being high in winter and low in summer, and that $\delta^{34} \mathrm{~S}$ values of non-sea salt sulfate in winter wet depositions contain sulfur related to coal combustion in East Asia (Ohizumi et al., 1997; Kawamura et al., 2002). Akata et al. (2002) suggested that the main source of sulfur compounds in Japanese winter wet deposition was the Asian continent.

For approximately 10 years since 1993 , we have monitored atmospheric aerosols at Tsuruoka, located on the Sea of Japan, and analyzed their chemical components and the $\delta^{34} \mathrm{~S}$ values of sulfate. We have already reported some of the $\delta^{34} \mathrm{~S}$ values (Motoyama et al., 2000). In the present study, we report long-term variation of atmospheric $\mathrm{SO}_{4}{ }^{2-}$ concentrations and $\delta^{34} \mathrm{~S}$ values of $\mathrm{SO}_{4}{ }^{2-}$ in aerosols from the area facing the Sea of Japan in order to clarify the influence of long-range transported sulfur compounds.

\section{Materials AND Methods}

\section{Sample collection}

Sampling was made on top of a building of the Tsuruoka National College of Technology in Tsuruoka City, Yamagata Prefecture, Japan ( $\left.38^{\circ} 42^{\prime} \mathrm{N}, 139^{\circ} 47^{\prime} \mathrm{E}\right)$, approximately $9 \mathrm{~km}$ away from the shore of the Sea of Japan and $20 \mathrm{~m}$ high above ground level (Fig. 1). Tsuruoka city is located on the western edge of the Shonai plain and is surrounded by high mountains. The sampling method was identical to that we used previously (Motoyama et al., 2000). Briefly, aerosol particles (TSP: total suspended particles) were collected during the period of November 1993 to December 2003, using a highvolume air sampler (HVC-1000; Sibata Scientific Technology Ltd.) on a $203 \mathrm{~mm} \times 254 \mathrm{~mm}$ PTEF filter (PF040; Advantec) and/or quartz fiber filters (QR-100; Advantec). The airflow rate was $700 \mathrm{~L} \mathrm{~min}^{-1}$. Sampling was made 334 times during 10 years, each of which consists of approximately 5-day sampling duration. In this study, we did not measure sample (aerosol particle) weight.

\section{Analytical methods}

A quarter of each filter was taken for extracting water-soluble components. The quarter filter was put into a Teflon vessel filled with distilled water. The watersoluble components were extracted ultrasonically for 5 min. The extracted solution was then filtered through a $0.45 \mu \mathrm{m}$ membrane filter (C045A047A; Advantec).

The concentrations of $\mathrm{Cl}^{-}, \mathrm{NO}_{3}{ }^{-}$, and $\mathrm{SO}_{4}{ }^{2-}$ were measured by ion chromatography (2020i; Dionex). Concentrations of $\mathrm{Na}^{+}$were determined using ICP-AES (SPS7000A; Seiko Instruments Inc.).

After chemical analyses, $\mathrm{SO}_{4}{ }^{2-}$ was precipitated as $\mathrm{BaSO}_{4}$ from the extracted solution for $\delta^{34} \mathrm{~S}$ analysis. For the $\delta^{34} \mathrm{~S}$ analysis, the $\mathrm{BaSO}_{4}$ precipitate was dried and converted to $\mathrm{SO}_{2}$ through thermal decomposition using a mixture of $\mathrm{SiO}_{2}-\mathrm{V}_{2} \mathrm{O}_{5}$ in a vacuum line (Yanagisawa and Sakai, 1983). Subsequently, $\delta^{34} \mathrm{~S}$ was measured using a 


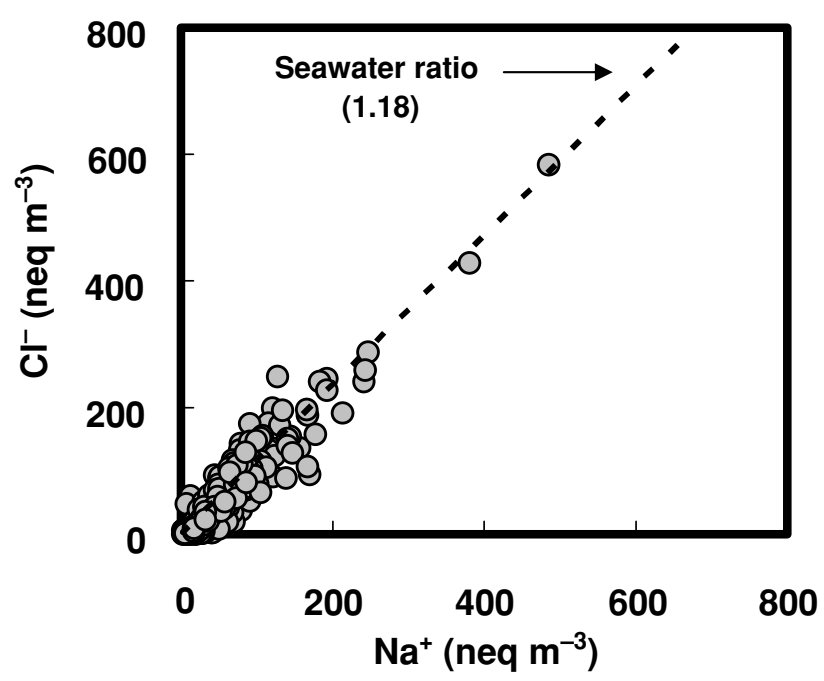

Fig. 2. Relationship between atmospheric $\mathrm{Na}^{+}$and $\mathrm{Cl}^{-}$equivalent concentrations in aerosol samples (-) and that of seawater ratio (dashed line: equivalent concentration ratio).

stable isotope ratio mass spectrometer (Optima; Micromass). The Canyon Diablo Troilite (CDT) scale was applied for reporting the $\delta^{34} \mathrm{~S}$ values, which is defined as

$$
\delta^{34} \mathrm{~S}=\left(\frac{\left({ }^{34} \mathrm{~S} /{ }^{32} \mathrm{~S}\right)_{\text {sample }}}{\left({ }^{34} \mathrm{~S} /{ }^{32} \mathrm{~S}\right)_{\text {std }}}-1\right) \times 1000
$$

where ${ }^{34} \mathrm{~S} /{ }^{32} \mathrm{~S}_{\text {sample }}$ and ${ }^{34} \mathrm{~S} /{ }^{32} \mathrm{~S}_{\text {std }}$ denote the ${ }^{34} \mathrm{~S} /{ }^{32} \mathrm{~S}$ ratios of sample and standard, respectively. The analytical precision, including the preprocessing operation, was better than $\pm 0.2 \%$. We used $\mathrm{BaSO}_{4}$ of NBS-127 $\left(\delta^{34} \mathrm{~S}_{\mathrm{CDT}}\right.$ : $+20.32 \pm 0.36 \%$ ) as secondary standard material. We obtained 178 data in total.

\section{RESULTS AND DISCUSSION}

Atmospheric concentration of $\mathrm{SO}_{4}{ }^{2-}$ and $\delta^{34} \mathrm{~S}$ of sulfate in aerosols

Figure 2 shows the relationship of $\mathrm{Na}^{+}$and $\mathrm{Cl}^{-}$concentration in aerosols with seawater ratio of $\mathrm{Na}^{+}$and $\mathrm{Cl}^{-}$ equivalent concentration. Almost all the samples are distributed along the sea water line, suggesting $\mathrm{Na}^{+}$and $\mathrm{Cl}^{-}$ originated from seawater. On the basis of $\mathrm{Na}^{+}$as the tracer for sea salt component, non-sea salt $\mathrm{SO}_{4}{ }^{2-}\left({ }_{\mathrm{nss}} \mathrm{SO}_{4}{ }^{2-}\right)$ concentration and $\delta^{34} S$ of non-sea salt sulfate $\left({ }_{n s s} \delta^{34} S\right)$ were calculated by the following equations:

${ }_{\mathrm{nss}} \mathrm{SO}_{4}{ }^{2-}={ }_{\mathrm{sam}} \mathrm{SO}_{4}{ }^{2-}-\frac{\text { sea }}{\mathrm{SO}_{4}{ }^{2-}} \mathrm{Na}_{\text {sea }} \mathrm{Na}^{+} \mathrm{Na}^{+}$

$$
\begin{aligned}
& { }_{\mathrm{nss}} \delta^{34} \mathrm{~S} \\
& =\frac{{ }_{\mathrm{sam}} \delta^{34} \mathrm{~S}_{\mathrm{sam}} \mathrm{SO}_{4}{ }^{2-}{ }_{\text {sea }} \delta^{34} \mathrm{~S} \times\left({ }_{\mathrm{sam}} \mathrm{SO}_{4}{ }^{2-}{ }_{{ }_{\mathrm{nss}}} \mathrm{SO}_{4}{ }^{2-}\right)}{\mathrm{nss}_{4} \mathrm{SO}^{2-}}
\end{aligned}
$$

where ${ }_{\mathrm{sam}} \mathrm{SO}_{4}{ }^{2-}$ and ${ }_{\text {sam }} \mathrm{Na}^{+}$are $\mathrm{SO}_{4}{ }^{2-}$ and $\mathrm{Na}^{+}$concentrations in each samples, ${ }_{\text {sea }} \mathrm{SO}_{4}{ }^{2-}$ and ${ }_{\text {sea }} \mathrm{Na}^{+}$are $\mathrm{SO}_{4}{ }^{2-}$ and $\mathrm{Na}^{+}$concentrations in sea water, ${ }_{\text {sam }} \delta^{34} \mathrm{~S}$ and ${ }_{\text {sea }} \delta^{44} \mathrm{~S}$ are $\delta^{34} \mathrm{~S}$ values of sample and seawater $(+20.3 \%$ : Rees et al., 1978).

Figure 3 shows the seasonal variations of $\mathrm{sam} \mathrm{SO}_{4}{ }^{2-}$ concentrations, ${ }_{n s s} \mathrm{SO}_{4}{ }^{2-}$ concentrations, and ${ }_{\text {sam }} \delta^{34} \mathrm{~S}$ and ${ }_{\mathrm{nss}} \delta^{34} \mathrm{~S}$ values of aerosols. Concentrations of ${ }_{\mathrm{sam}} \mathrm{SO}_{4}{ }^{2-}$ and ${ }_{n s s} \mathrm{SO}_{4}{ }^{2-}$ range from 7.6 to 354.4 neq m$^{-3}$ and 3.7 to 335.6 neq $\mathrm{m}^{-3}$, respectively, and the variations of ${ }_{\mathrm{sam}} \mathrm{SO}_{4}{ }^{2-}$ and ${ }_{n s s} \mathrm{SO}_{4}{ }^{2-}$ concentrations decrease gradually and reach the minimum in 1999. Afterwards, they become greater the years of 2000 to 2003 . This trend is similar to other longterm observations (Ito and Mizohata, 2006). There is no clear seasonal variation, although ${ }_{\mathrm{nss}} \mathrm{SO}_{4}{ }^{2-}$ concentrations are slightly high in summer.

The ${ }_{\text {sam }} \delta^{34} \mathrm{~S}$ and ${ }_{\mathrm{nss}} \delta^{34} \mathrm{~S}$ in aerosols range from +1.0 to +15.1 with a mean value of $+5.7 \%$, and from -4.4 to +14.5 with a mean value of $+4.1 \%$, respectively. Variation ranges of ${ }_{\text {sam }} \delta^{34} \mathrm{~S}$ and ${ }_{\mathrm{nss}} \delta^{34} \mathrm{~S}$ values abruptly narrowed after 2000. Kawamura et al. (2002) reported ${ }_{n s s} \delta^{34} S$ values of aerosols collected at Fukuoka, located in Kyushu Island, Japan, ranged from +0.4 to $4.9 \%$ during March 1999 to January 2000. These results are comparable to our results obtain in the same period.

To detect the seasonal variation, we plot seasonal mean ${ }_{\text {sam }} \delta^{34} \mathrm{~S}$ and ${ }_{\mathrm{nss}} \delta^{34} \mathrm{~S}$ values with the variation range (spring, March-May; summer, June-August; fall, SeptemberNovember; winter, December-February) in Fig. 4. The average values of ${ }_{\text {sam }} \delta^{34} S$ and ${ }_{n s s} \delta^{34} S$ are slightly lower in summer and high in the other three seasons, in which they are almost at the same level. The ${ }_{\text {sam }} \delta^{34} \mathrm{~S}$ values are lower than the values of sea salt sulfate $(+20.3 \%$ ). The difference of ${ }_{\text {sam }} \delta^{34} \mathrm{~S}$ and ${ }_{\mathrm{nss}} \delta^{34} \mathrm{~S}$ values in summer is smaller than in other three seasons, which indicates that contributions of sea-salt sulfate are low in summer (average: $3.5 \%$ ) and high during the other seasons (average: 12.2\%).

\section{Source identification of sulfate in aerosols}

The seasonal variations of ${ }_{n s s} \delta^{34} \mathrm{~S}$ values suggest that ${ }_{n s s} \mathrm{SO}_{4}{ }^{2-}$ in aerosols are derived from sources with lower $\delta^{34} \mathrm{~S}$ values in summer than in other seasons. Atmospheric sulfur compounds originate mainly from four natural and anthropogenic sources: industrial (anthropogenic) sulfur, bacteriogenic sulfur, sea spray sulfate, and volcanic sulfur. Regarding the cause of the high values of ${ }_{n s s} \delta^{34} \mathrm{~S}$ except summer, bacteriologic hydrogen sulfide and volcanic 


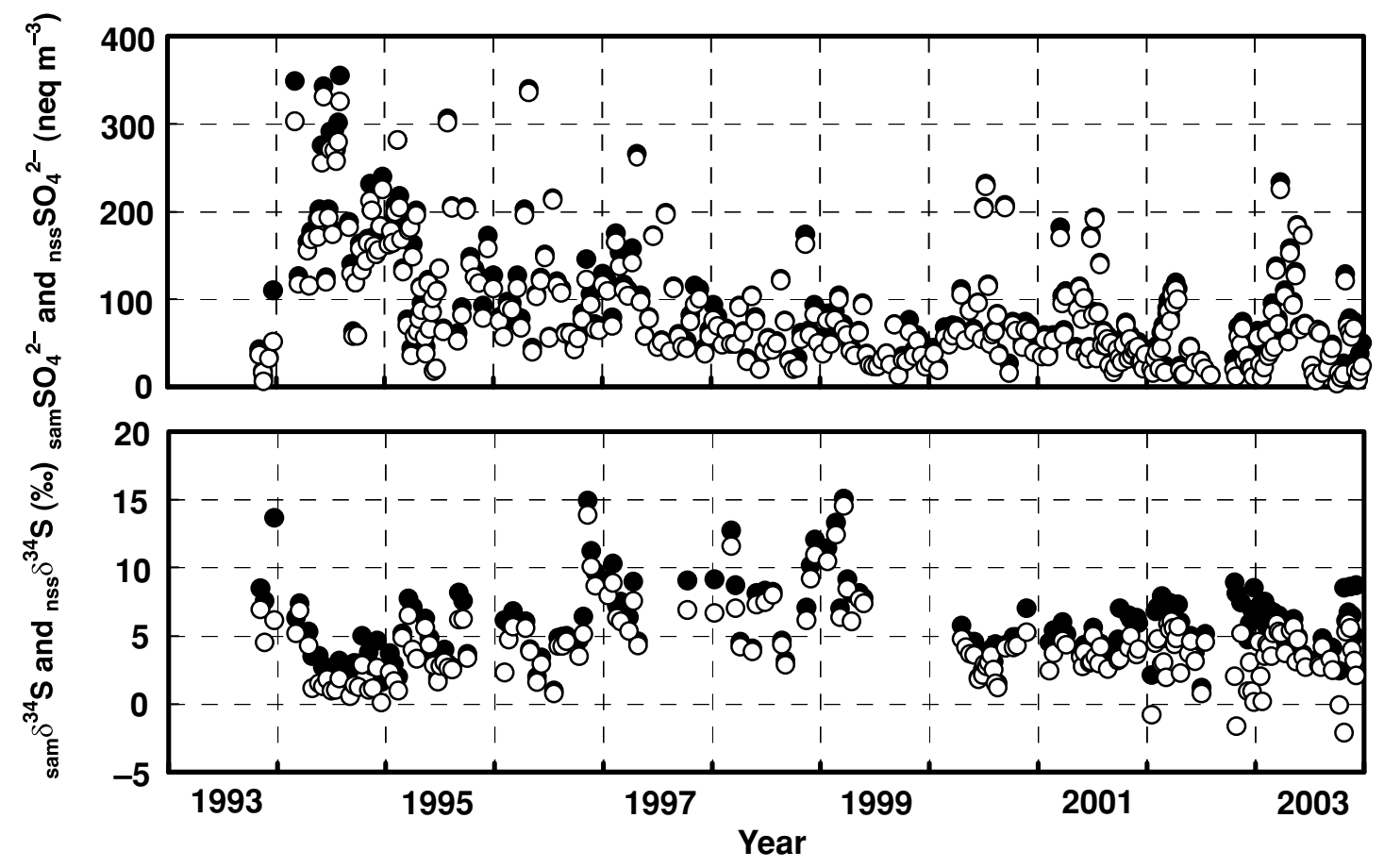

Fig. 3. Seasonal variation of (a) atmospheric ${ }_{\text {sam }} \mathrm{SO}_{4}{ }^{2-}(\mathbf{O})$ and ${ }_{n s s} \mathrm{SO}_{4}{ }^{2-}(\bigcirc)$ concentrations and $(b){ }_{\text {sam }} \delta^{34} \mathrm{~S}(\mathbf{O})$ and ${ }_{n s s} \delta^{34} \mathrm{~S}(\mathrm{O})$ values of aerosols collected at Tsuruoka, Japan in the period of 1993-2003.

sulfur are less likely sources, because bacterial activity occurs mainly in summer (Hatakeyama, 1985) with low $\delta^{34} \mathrm{~S}$ values (Nakai and Jensen, 1967), and there was no large-scale volcanic activity during the period of sampling, except for the Miyake-jima eruption in 2000 (Akata et al., 2004). During fall to spring, northwesterly monsoons blow into Japan and carry air masses including many kinds of materials from the Asian continent. On the other hand, high-pressure systems develop in the Pacific Ocean in summer, and bring air masses to Japan from the ocean. Therefore, effect of the continental source will be small in summer. It seems that ${ }_{n s s} \delta^{34} \mathrm{~S}$ values in summer are the background values of the sampling area (which has a mixture of local anthropogenic sulfur and local biogenic sulfur), and ${ }_{n s s} \delta^{34} S$ values in other three seasons are composites of the background values and values of other origins.

China is located in the windward of the northwesterly monsoon. In China, many consecutive years of high economic growth in this period were accompanied by increasing energy demands, greater coal combustion, and even greater emissions of pollutants (Fu et al., 2007). Therefore, gases and aerosols (fly ash) discharged by fossil fuel combustion have created serious environmental problems. The main fossil fuel used in China is coal, and anthropogenic $\mathrm{SO}_{4}{ }^{2-}$ aerosols in the atmosphere are mainly produced by oxidation of $\mathrm{SO}_{2}$ emitted by coal combustion.

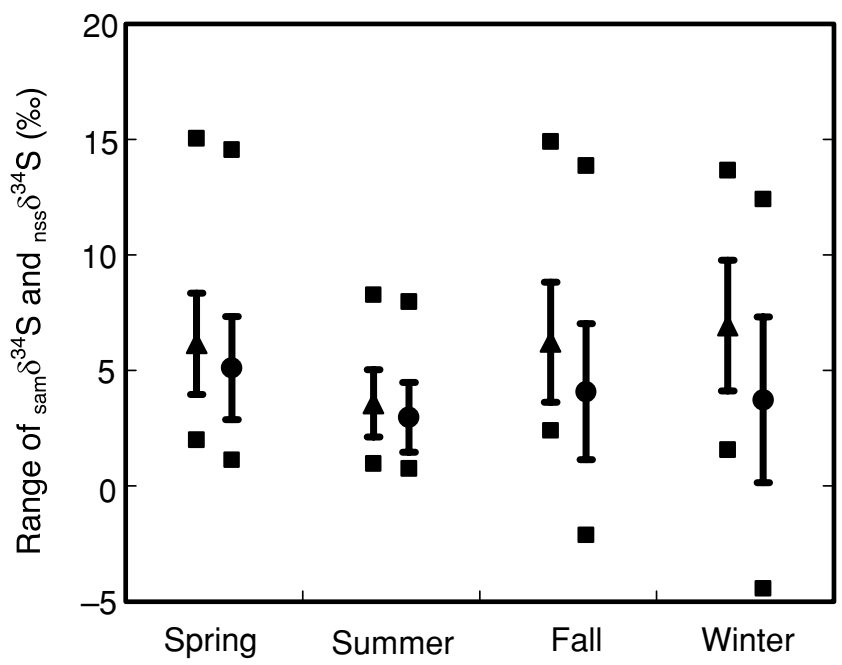

Fig. 4. Maximum and minimum values (-), mean values and ranges of ${ }_{\text {sam }} \delta^{34} S(\mathbf{\Delta})$ and ${ }_{n s s} \delta^{34} S(\mathbf{O})$ in aerosols during the four seasons at Tsuruoka, Japan (error bars show S.D.).

To identify the sources of ${ }_{\mathrm{nss}} \delta^{34} \mathrm{~S}$ in wet deposition, which is high in winter, Ohizumi et al. (1997) investigated the $\delta^{34} \mathrm{~S}$ in wet deposition and fossil fuels. They found that the $\delta^{34} \mathrm{~S}$ values of wet deposition in Niigata in winter were in agreement with the $\delta^{34} \mathrm{~S}$ values of coal used in China 
(greater than $+6.0 \%$ ). The $\mathrm{SO}_{4}{ }^{2-}$ aerosols produced by homogenous and heterogeneous oxidation reactions are enriched in heavier sulfur isotopes than atmospheric $\mathrm{SO}_{2}$ (Saltzman et al., 1983; Mukai et al., 2001). Kawamura et al. (2002) suggested that there was a strong possibility of long-range transport of $\mathrm{SO}_{4}{ }^{2-}$ from continental Asia to the southern Japanese island of Kyushu, because the high ${ }_{n s s} \delta^{34} \mathrm{~S}$ values in winter bulk precipitation could not be explained only by the isotopic fractionation effect of these oxidation reactions in a fluid layer on the aerosol surface. The main fossil fuel used in Japan is petroleum imported mainly from the Middle East countries. Ohizumi et al. (1997) reported $\delta^{34} \mathrm{~S}$ values of petroleum used in Japan ranged from $-8.2 \%$ to $+7.2 \%$ with a mean value of $-3.3 \%$. Maruyama et al. (2000) also reported they ranged from $-6.8 \%$ to $+9.1 \%$ with mean value of $-0.64 \%$. Therefore, the contribution of sulfur compounds produced by petroleum combustion in Japan is thought to be small. During the coal combustion process in industrial and domestic uses of coal as fuel, released gaseous sulfur compounds such as $\mathrm{SO}_{2}$ are invariably enriched in lighter sulfur isotopes relative to the corresponding coal. In contrast, particles such as fly ash are always rich in heavier sulfur isotopes (Hong et al., 1993). The ${ }_{n s s} \delta^{34} \mathrm{~S}$ in aerosols in fall to spring are close to the average $\delta^{34} \mathrm{~S}$ values of coal used in northern China which range from 0 to $+15 \%$ with a mean value of $+7.4 \pm 8.8 \%$ (Motoyama $e t$ $a l ., 2002)$. These results indicate that the long-range transport of sulfate from the Asian continent to Japan might be the source of the high ${ }_{n s s} \delta^{34} \mathrm{~S}$ values in fall to spring.

On the other hand, sulfate salts are included in the source materials of Asian dust and are therefore inferred to contribute to long-range transport of those components. Yabuki et al. (1999) reported that $\delta^{34} \mathrm{~S}$ values of salt materials collected in the Xinjiang Province varied widely, -30.3 to $+26.1 \%$, with the most frequently occurring values of +5 and $+10 \%$ o. Yanagisawa et al. (1997) also reported $\delta^{34} \mathrm{~S}$ values of +5 to $+18 \%$ for desert sand and loess collected in the Taklimakan Desert and Loess Plateau. These values are higher than those of sulfate in aerosols. The relationship between the ${ }_{\mathrm{nss}} \delta^{34} \mathrm{~S}$ in aerosols and those in desert sand and loess remains unclear. High $\delta^{34} \mathrm{~S}$ values sometimes appear during spring and fall. Therefore, one of the sources of $\mathrm{SO}_{4}{ }^{2-}$ in atmospheric aerosols in spring and fall could be desert sand and loess $\mathrm{SO}_{4}{ }^{2-}$ transported from the arid and semi-arid regions of China.

Change of the trend of $\mathrm{SO}_{4}{ }^{2-}$ concentration and $\delta^{34} \mathrm{~S}$ values

As mentioned before, the trend of ${ }_{\text {sam }} \mathrm{SO}_{4}{ }^{2-}$ and ${ }_{n s s} \mathrm{SO}_{4}{ }^{2-}$ concentrations reaches the minimum in 1999. To prevent the increase in anthropogenic emissions of pollutants and consumption of coal, China enacted the "Air Pollution Control Act" for environmental protection in

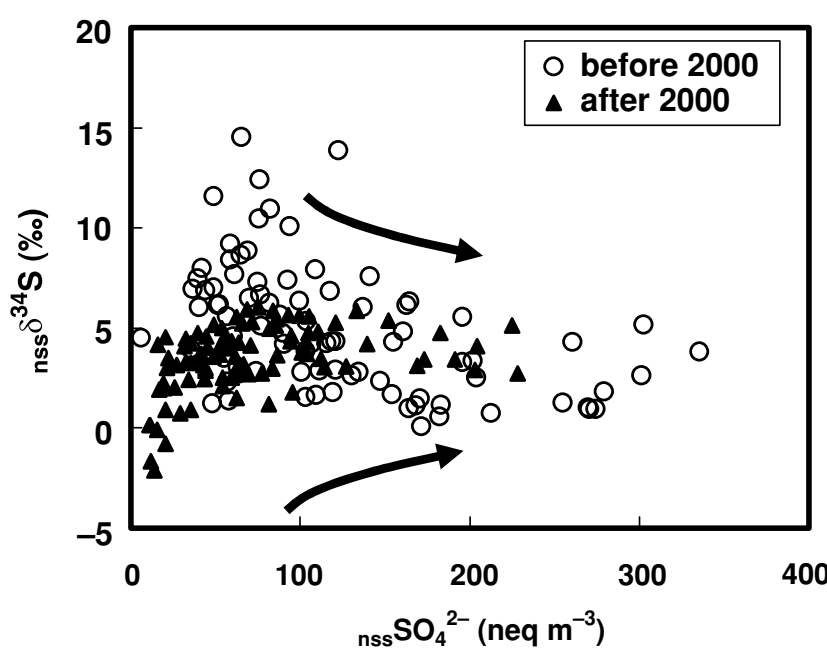

Fig. 5. Non-sea salt sulfate concentrations versus ${ }_{n s s} \delta^{34} S$ in aerosol samples collected at Tsuruoka, Japan in the period of 1993-2003.

1978. This act was revised to provide better air quality protection in 1995 (Study Group on China Environmental Problem, 2004). The energy structure changed from coal to petroleum and clean fuels (nuclear energy and hydroelectricity) (Fang et al., 2009) with application of pollution control technologies to plants. As a result, among the fuel consumptions, only the amount of coal has decreased since 1997 with the minimum in 2000 (Akimoto et al., 2006). The $\mathrm{SO}_{2}$ emission in China slightly decreased from 1995 to 2002 (Ohara et al., 2007). On the other hand, the numbers of motor vehicles in China have been rapidly increasing since 1990 (Liu and Diamond, 2005). Carmichael et al. (2002) suggested that the decline of $\mathrm{SO}_{2}$ emissions in China was due to a reduction in industrial coal use, a slowdown of the Chinese economy, and the closure of small and inefficient plants among other reasons. Therefore, the changes in energy structure in China would have caused the decreasing trend of ${ }_{\mathrm{nss}} \mathrm{SO}_{4}{ }^{2-}$ concentration in aerosols transported from China to Tsuruoka.

The variation ranges of ${ }_{\text {sam }} \delta^{34} \mathrm{~S}$ and ${ }_{n s s} \delta^{34} \mathrm{~S}$ values abruptly changed after 2000. Relationships between ${ }_{n s s} \mathrm{SO}_{4}{ }^{2-}$ concentrations and ${ }_{n s s} \delta^{34} \mathrm{~S}$ in aerosols are shown in Fig. 5. The ${ }_{n s s} \delta^{34} \mathrm{~S}$ values converge to around 0 to $5 \%$ with increasing in ${ }_{n s s} \mathrm{SO}_{4}{ }^{2-}$ concentration. Almost all ${ }_{n s s} \delta^{34} \mathrm{~S}$ values in summer are around 0 to $+5 \%$ (Fig. 4 ), and ${ }_{n s s} \mathrm{SO}_{4}{ }^{2-}$ concentrations are slightly higher in summer than other three seasons. It means that they probably originated from local sulfur sources. We can interpret Fig. 5 as showing the mixing of sulfur sources (local sulfur with 0 to $+5 \%$, continental sulfur with high $\delta^{34} \mathrm{~S}$ values and other sulfur with low $\delta^{34} \mathrm{~S}$ values). In China, besides 
the changes in energy structure mentioned above, environmental protection regulations are being revised steadily since 1995, and Chinese economic growth is gradually being controlled by stronger policies. To control sulfur emissions, China has introduced the technologies for improving combustion efficiency and fuel gas desulfurization (FGD) technologies for removal of TSP and $\mathrm{SO}_{2}$. Zhang (2005) reported that FGD technologies (wet-based) were introduced to industrial plants of coke production and thermal power station since 1998 at Shanxi Province, from which the air-mass flows into Yamagata prefecture during fall to spring, and that over $40 \%$ of the plants had accepted the technologies by 2001. These technologies can enrich the lighter sulfur isotopes into released $\mathrm{SO}_{2}$ (Derda et al., 2007), which would have caused the abrupt change in the variation ranges of ${ }_{\text {sam }} \delta^{34} \mathrm{~S}$ and ${ }_{\mathrm{nss}} \delta^{34} \mathrm{~S}$ values after 2000 .

\section{Conclusions}

Aerosol samples were collected in an area of Japan on the Sea of Japan during 10 years. Concentrations of water-soluble chemical components and sulfur isotopic ratios of sulfate in the samples were measured to evaluate their temporal variations and identify the sulfate source.

(1) The ${ }_{\mathrm{sam}} \mathrm{SO}_{4}{ }^{2-}$ and ${ }_{\mathrm{nss}} \mathrm{SO}_{4}{ }^{2-}$ concentrations range from 7.6 to 354.4 and 3.7 to $335.6 \mathrm{neq}^{-3}$, respectively, and show no clear seasonal variation.

(2) Sulfur isotope ratios of sulfate $\left({ }_{\mathrm{sam}} \delta^{34} \mathrm{~S}\right)$ and nonsea salt sulfate $\left({ }_{n s s} \delta^{34} \mathrm{~S}\right)$ in aerosols range from +1.0 to +15.1 with a mean value of $+5.7 \%$ and -4.4 to +14.5 with a mean value of $+4.1 \%$, respectively.

(3) The values of ${ }_{\text {sam }} \delta^{34} \mathrm{~S}$ and ${ }_{\mathrm{nss}} \delta^{34} \mathrm{~S}$ are relatively low in summer and high in the other three seasons, suggesting that ${ }_{\mathrm{nss}} \mathrm{SO}_{4}{ }^{2-}$ in aerosols was derived from sources with lower $\delta^{34} \mathrm{~S}$ values in summer than in the other three seasons. The most important source of sulfur compounds in aerosols in fall to spring is anthropogenic sulfur produced by fossil fuel combustion on the Asian continent.

(4) The ${ }_{n s s} \mathrm{SO}_{4}{ }^{2-}$ concentrations in aerosols decrease gradually and reach the minimum in 1999, which would be caused by the decline of $\mathrm{SO}_{2}$ emissions in China due to a reduction in industrial coal use, a slowdown of the Chinese economy, and the closure of small and inefficient plants among other reasons.

(5) The variation ranges of ${ }_{\text {sam }} \delta^{34} \mathrm{~S}$ and ${ }_{n s s} \delta^{34} \mathrm{~S}$ values abruptly changed after 2000. The introduction of flue gas desulfurization (FGD) technologies to industrial plants of coke production would be one of the most important causes of this change.

Acknowledgments-We gratefully acknowledge laboratory coworkers and A. Kawabata (Mitsubishi Material Corp.) for their help in sample analysis. We are also grateful to Drs. H. Kawamura of Kyushu Environmental Evaluation Association, $\mathrm{H}$. Hasegawa of Institute for Environmental Sciences and anonymous reviewers for their fruitful discussion.

\section{REFERENCES}

Akata, N., Yanagisawa, F., Motoyama, R., Kawabata, A. and Ueda, A. (2002) Sulfur isotope ratio of non-sea salt sulfate in wet deposits in Japan. Seppyo 64, 173-184 (in Japanese with English abstract).

Akata, N., Yanagisawa, F., Takigami, Y., Motoyama, R., Kawabata, H., Yabuki, S., Kanayama, S., Kawabata, A. and Ueda, A. (2004) The contribution of volcanic eruptions of Miyake Island to sulfur isotope ratios of sulfate in atmospheric bulk deposition in metropolitan Tokyo, Japan. J. Jpn. Atmos. Environ. 39, 21-30.

Akimoto, H., Ohara, T., Kurokawa, J. and Horii, N. (2006) Verification of energy consumption in China during 1996-2003 by using satellite observational data. Atmos. Environ. 40, 7663-7667.

Arndt, R. L. and Carmichael, G. R. (1995) Long-range transport and deposition of sulfur in Asia. Water, Air Soil Pollut. 85, 2283-2288.

Carmichael, G. R., Streets, D. G., Calori, G., Amann, M., Jacobson, M. Z., Hansen, J. and Ueda, H. (2002) Changing trends in sulfur emissions in Asia: Implications for acid deposition, air pollution, and climate. Environ. Sci. Tech. 36, 47074713.

Derda, M., Chmielewski, A. G. and Licki, J. (2007) Sulphur isotope compositions of components of coal and S-isotope fractionation during its combustion and flue gas desulphurization. Isot. Environ. Health Stud. 43, 57-63.

Fang, M., Chan, C. K. and Yao, X. (2009) Managing air quality in a rapidly developing nation: China. Atmos. Environ. 43, 79-86.

Fu, B. J., Zhuang, X. L., Jiang, G. B., Shi, J. B. and Lü, Y. H. (2007) Environmental problems and challenges in China. Environ. Sci. Technol. 41, 7597-7602.

Fuller, R. D., Mitchell, M. J., Krouse, H. R., Wyskowski, B. J. and Driscoll, C. T. (1986) Stable sulfur isotope ratios as a tool for interpreting ecosystem sulfur dynamics. Water, Air Soil Pollut. 28, 163-171.

Guttikunda, S. K., Carmichael, G. R., Calori, G., Eck, C. and Woo, J. H. (2003) The contribution of megacities to regional sulfur pollution in Asia. Atmos. Environ. 37, 11-22.

Hatakeyama, S. (1985) Emission of reduced-sulfur compounds into the atmosphere and oxidation of those compounds in the atmosphere-contribution to the global sulfur cycleJ. Japan Soc. Air Pollut. 20, 1-11 (in Japanese with English abstract).

Hong, Y., Zhang, H. and Zhu, Y. (1993) Sulfur isotopic characteristics of coal in China and sulfur isotopic fractionation during coal-burning process. Chinese J. Geochem. 12, 5159.

Ito, N. and Mizohata, A. (2006) Long term (1986-2004) observation of atmospheric aerosols at Sakai, Osaka. J. Aerosol Res. 21, 297-304 (in Japanese with English abstract).

Kawamura, H., Tawaki, S., Matsuoka, N., Nagano, T., 
Momoshima, N., Osaki, S. and Maeda, Y. (2002) Sulfur isotopic compositions and source identification of atmospheric sulfur dioxide, sulfate in aerosols and in bulk precipitation collected over Kyushu Island, Japan. Chikyukagaku (Geochemistry) 36, 23-33 (in Japanese with English abstract).

Koçak, M., Kubilay, N. and Mihalopoulos, N. (2004) Ionic composition of lower tropospheric aerosols at a northeastern Mediterranean site: implications regarding sources and longrange transport. Atmos. Environ. 38, 2067-2077.

Liu, J. and Diamond, J. (2005) China's environment in a globalizing world. Nature 435, 1179-1186.

Maruyama, T., Ohizumi, T., Taneoka, Y., Minami, N., Fukuzaki, N., Mukai, H., Murano, K. and Kusakabe, M. (2000) Sulfur isotope ratios of coals and oils used in China and Japan. Nippon Kagaku Kaishi 1, 45-51 (in Japanese with English abstract).

Motoyama, R., Yanagisawa, F., Kotani, T., Kawabata, A. and Ueda, A. (2000) Sulfur isotope ratio of non-sea salt sulfate in aerosol and wet deposition in Yamagata, Japan. Seppyo 62, 215-224 (in Japanese with English abstract).

Motoyama, R., Yanagisawa, F., Akata, N., Suzuki, Y., Kanai, Y., Kojima, T., Kawabata, A. and Ueda, A. (2002) Sulfur isotope ratios of coals used in East Asia. Seppyo 64, 49-58 (in Japanese with English abstract).

Mukai, H. Tanaka, A., Fujii, T., Zeng, Y., Hong, Y., Tang, J., Guo, S., Xue, H., Sun, Z., Zhou, J., Xue, D., Zhao, J., Zhai, G., Gu, J. and Zhai, P. (2001) Regional characteristics of sulfur and lead isotope ratios in the atmosphere at several Chinese urban sites. Environ. Sci. Technol. 35, 1064-1071.

Nakai, N. and Jensen, M. L. (1967) Sources of atmospheric sulfur compounds. Geochem. J. 1, 199-210.

Ohara, T., Akimoto, H., Kurokawa, J., Horii, N., Yamaji, K., Yan, X. and Hayasaka, T. (2007) An Asian emission inventory of anthropogenic emission sources for the period 1980
2020. Atmos. Chem. Phys. 7, 4419-4444.

Ohizumi, T., Fukuzaki, N. and Kusakabe, M. (1997) Sulfur isotopic view on the sources of sulfur in atmospheric fallout along the coast of the Sea of Japan. Atmos. Environ. 31, 1339-1348.

Rees, C. E., Jenkins, W. J. and Monster, J. (1978) The sulphur isotopic composition of ocean water sulphate. Geochim. Cosmochim. Acta 42, 377-381.

Saltzman, E. S., Brass, G. W. and Price, D. A. (1983) The mechanism of sulfate aerosol formation: Chemical and sulfur isotopic evidence. Geophys. Res. Lett. 10, 513-516.

Study Group on China Environmental Problem 2005-2006 (2004) China Environmental Handbook (Asuka, J., Kataoka, N., Otsuka, K. and Aikawa, T., eds.), Soso-sha, Tokyo (in Japanese).

Yabuki, S., Okada, A., Ueda, A. and Chang, Q. (1999) Sulfur isotope study of the source materials of the Aeolian dust of inland Asia. Geochemistry of the Earth's Surface (Àrmannsson, H., ed.), 65-68, Balkema, Rotterdam.

Yanagisawa, F. and Sakai, H. (1983) Thermal decomposition of barium sulfate-vanadium pentaoxide-silica glass mixture for preparation of sulfur dioxide in sulfur isotope ratio measurement. Anal. Chem. 55, 985-987.

Yanagisawa, F., Obinata, Y., Ito, H., Ueda, A., Kanai, Y. and Yabuki, S. (1997) Sulfate ion in atmospheric deposition in Japan (2) Seasonal variation of sulfur isotope ratios of aerosols in Yamagata Prefecture. Proc. Int. Cong. Acid Snow and Rain, Niigata, 149-154.

Zhang, X. (2005) Environmental Improvement and Global Warming Control Using CDM. 113-130, Sofu-sha Press (in Japanese).

Zhao, F. J., Knights, J. S., Hu, Z. Y. and McGrath, S. P. (2003) Stable sulfur isotope ratio indicates long-term changes in sulfur deposition in the Broadbalk experiment since 1845 . J. Environ. Qual. 32, 33-39. 